\title{
The Effectiveness of Student Worksheet (LKM) Based on Guided Discovery Learning on Matrix Material of Building Engineering Education Students
}

\author{
Enny Keristiana Sinaga ${ }^{1}$, Zulkifli Matondang ${ }^{2}$, Suhairiani ${ }^{3}$, Siti Zulfa Yuzni ${ }^{4}$ \\ \{ennysinaga@unimed.ac.id ${ }^{1}$ \} \\ ${ }^{1,2,3,4}$ Universitas Negeri Medan, Indonesia
}

\begin{abstract}
The need for teaching materials that are able to facilitate and guide students for independent learning makes it easier for students to find and understand concepts correctly as the background of this research. Text books have not been able to help students understand and remember mathematical concepts well. Therefore, a concept of "Student Work Sheet" (LKM) based on guided discovery learning on matrix material was developed. After the SWS developed, it has shown the effectiveness of the use of the SWS in the learning process. The subjects of this study were students of Building Engineering Education Study Program at the State University of Medan that were able to study basic engineering mathematics courses. Based on the analysis it was found that the percentage of post-test was greater than the percentage of pretest $(84,85>24,24 \%)$ and was filed in the Good criteria and the results of paired simple-t test showed that the value of $t_{\text {count }}$ $(18,3715)>t_{\text {table }}(2,037)$. This means that LKM based on guided discovery learning is declared effective for use.
\end{abstract}

Keyword: Effectiveness, Guided Discovery Learning, Student Worksheet.

\section{Introduction}

Matrix material is one of the basic subjects of Basic Engineering Mathematics taught in the Building Engineering Education Study Program in semester I. This material must be mastered by students because it is one of the materials that supports (compatible) with other engineering subjects such as structure analysis courses. It is expected that by studying matrix material, students can: (1) explain the characteristics of a matrix, (2) write information in the form of a matrix, (3) recognize a square matrix, (4) perform algebraic operations on two matrices, (5) reduce the properties matrix operations through examples, (6) Determine the determinant of a matrix, (7) determine the inverse of a matrix, and (8) Solve a set of linear equations and solve problems related to the field of civil engineering.

Based on the researchers' experience and the results of interviews / discussions with the teaching team of basic mathematics courses in the Building Engineering Education Study Program, the matrix material is one of the materials that is difficult for students to understand. Difficulties faced by students are the inability of students to solve more complex matrix problems, such as applying the matrix in a broader context and in the context of everyday life. This is due to the low understanding of students' mathematical concepts. In other words, the lack of understanding of the concept of student matrices causes students to be unable to solve 
problems related to more complex matrices, which demand critical thinking skills.

Based on the difficulties experienced by students in solving mathematical problems shows the importance of understanding the concepts contained in mathematics. Therefore, understanding previous concepts in mathematics is a prerequisite for understanding subsequent concepts, so the implications for learning mathematics must be gradual and sequential systematically and based on past learning experiences.

Students will understand the material well if students learn the material independently. One alternative teaching material that can be developed to direct the mindset of students and build student independence is the Student Worksheet (LKM). LKM contains assignments and steps that guide students to manage mindset in a directed manner. The role of the lecturer as a facilitator can be maximized. With LKM students are expected to be able to study independently, understand and carry out a written form [1].

Many educators were still using conventional teaching materials, namely teaching materials that were left in use, left to buy, instant, and without preparing and compiling themselves [5]. Where the teaching material is not contextual, not interesting, monotonous and does not fit the needs of students. As one of the lecturers supporting basic engineering mathematics courses, teaching materials used during the learning process are only in the form of one textbook. The textbook that is used has not provided an opportunity for students to find concepts from a material and coupled with the lazy attitude of reading students make problem solving in textbooks must still be explained by the lecturer. Seeing the existing problems, it is necessary to have teaching material as a companion to textbooks. The intended teaching material is teaching material that can guide students in understanding the material being taught. One of the textbooks accompanying teaching materials that is able to guide students to active and independent learning is LKM (Student Worksheet).

Student Worksheet is one of the tools that can be used by the teacher (lecturer) to increase student involvement in the learning process [4]. This is because, LKM has its own advantages compared to other teaching materials, one of the advantages of LKM is the content of LKM has summarized from several sources presented in a simpler form so that it is easy for students to understand.

Constructivism learning theory and discovery learning theory Bruner explains that students (students) must discover new knowledge by themselves based on prior knowledge, so students play an active role in the discovery process and are believed to be able to provide good results. The learning process will run well and creatively if the teacher (lecturer) provides an opportunity for students to find a concept, theory, rules, or understanding through the examples found [2].

Based on the characteristics of students of the Building Engineering Education Study Program, Faculty of Engineering, University of Medan, a suitable finding is that students find concepts through guidance and direction from lecturers because in general most students still need basic concepts to be able to find something. So students can process and construct their own knowledge, while lecturers guide them in the right direction.

Guided discovery learning methods are learning methods that regulate teaching in such a way that students gain knowledge, which they did not know before, not through notification but partially or wholly discovered by students themselves. The syntax of guided discovery learning that has been adapted is as follows: 1) Explain the purpose / prepare students; 2) Student orientation on problems; 3) Formulate a hypothesis; 4) Conduct guided discovery activities; 5) Present the results of guided discovery activities; 6) Evaluate guided discovery activities [6].

The purpose of this study is to examine the effectiveness of using student worksheets (LKM) based on guided findings on matrix material. Thus this study is entitled "The Effectiveness of Using Student Worksheets (LKM) Based on Guided Findings on Student 
Matrix Materials in Building Engineering Education Study Programs". Therefore, learning basic technical mathematics, especially on matrix material, should use a guided discovery-based student worksheet (LKM) that is expected to be effective.

\section{Research method}

This type of research is research and development. Research and development methods are research methods used to produce certain products and test the effectiveness of these products [5]. The product produced from this research is the effectiveness of MFI based on the discovery of matrix material. Development of MFIs based on guided matrix material is carried out using a 4-D model that has been modified to become 3-D. Consisting of three stages of development, namely the definition (Define), design (Design), development (Develop). This research was carried out until the development stage due to time constraints.

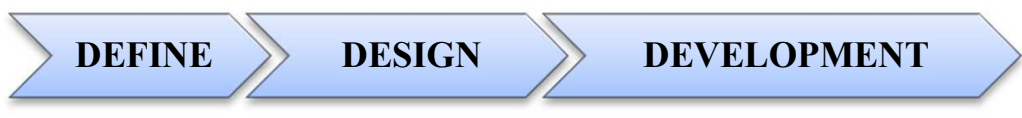

Fig1. Research Design, Research and Development 4-D Model

The define stage is defining the learning objectives contained in the curriculum by conducting (a) curriculum analysis which aims to look at Competency Standards (SK) and Basic Competencies (KD) as stated in the content standards with due regard to the syllabus and assessment system; suitable learning strategies and literature related to LKM based on guided discovery, (b) student analysis to see the difficulties faced by students during the mathematics learning process in class, and (c) concept analysis which is a collection of procedures for determining the content of a lesson.

The design phase which aims to design LKM based on guided discoveries for teaching in accordance with the specified indicators and learning objectives. This stage begins with the preparation of the LKM which is the first step to link define and design stages, and continues with the selection of the LKM format that is tailored to the needs needed in the LKM.

The development phase includes the LKM's validation by material experts and media experts. LKM are validated from the aspects of content worthiness, presentation worthiness, graphic worthiness and language worthiness. A valid LKM is then tested to find out its practicality and effectiveness in learning basic engineering mathematics.

This research data consists of quantitative and qualitative data. Quantitative data is carried out through concept understanding tests on the experimental class and the control class. The form of test used is the essay test. The data obtained in the form of the results of the pretest, posttest, and analyzed statistically using paired t-test with a confidence level of 5\%. The effectiveness analysis was assessed from the concept understanding test in the form of pretest and posttest. To determine the classification of data interpretation the following guidelines are used: 
- Calculate the Average Pretest Value

$\overline{\mathrm{x}}_{0}=\frac{\sum \mathrm{x}_{1}}{\mathrm{n}}$

- Calculate the Average Posttest Value

$$
\bar{x}_{1}=\frac{\sum x_{1}}{n}
$$

- Calculate the percentage of mastery leaming by understanding concepts in the posttest obtained by formulas:

Percentage of completeness $(p)=\frac{\text { Number of students who have finished }}{\text { The total number of students }} \times 100 \%$

(3)

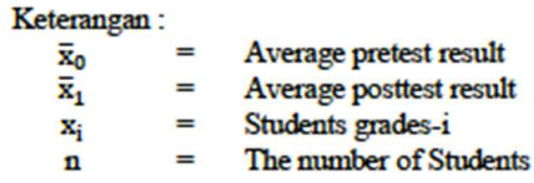

The following are guidelines that will determine the interpretation of student learning completeness data presented in Table 1 [3].

Table 1. Criteria for Evaluation of Concept Understanding Ability Test

\begin{tabular}{ll}
\hline Range & Criteria \\
\hline$p>80$ & Very Good \\
$60<p \leq 80$ & Good \\
$40<p \leq 60$ & Good Enough \\
$20<p \leq 40$ & Poorly \\
$p \leq 20$ & Very Poor \\
\hline
\end{tabular}

Teaching material (LKM) based on guided discovery learning to improve the ability of understanding the concept of PTB students Semester I (odd) Academic Year 2019/2020 is considered effective if the percentage of posttest is greater than the percentage of pretest and Good classification.

Teaching material (LKM) based on guided discovery learning to improve the ability of understanding the concept of PTB students Semester I (odd) Academic Year 2019/2020 is considered effective if the percentage of posttest is greater than the percentage of pretest and Good classification.

The formula for paired t-test is as follows:

$$
\begin{aligned}
t_{\text {count }} & =\frac{\bar{d}}{S_{d} / \sqrt{n}} \\
\operatorname{dimana}: & \\
\bar{d} & =\frac{\sum_{l}^{n} d_{i}}{n} \operatorname{dan} S_{d}=\sqrt{\frac{\sum_{l}^{n}\left(d_{i}-d\right)^{2}}{n-1}}
\end{aligned}
$$




\section{Result and discussion}

\section{Effectiveness of Student Worksheets (LKM)}

The effectiveness test of statistic textbooks was conducted on 33 students. Effectiveness is obtained from the value of learning outcomes data from test results, namely pre-test before being treated (treatment) and post-test after being treated (treatment). Learning outcomes here are included to find out the improvement in learning outcomes after the pretest and posttest. This test aims to determine whether a certain value (which is given as a comparison).

The effectiveness test aims to determine the effectiveness of the LKM.

The average pretest scores obtained are:

$$
\begin{aligned}
& \overline{\mathrm{x}}_{\text {pretest }}=\frac{\sum \mathrm{x}_{\mathrm{i}}}{\mathrm{n}}=\frac{1780}{33}=53,94 \\
& \text { While the average posttest score obtained is : } \\
& \overline{\mathrm{x}}_{\text {posttest }}=\frac{\sum \mathrm{x}_{\mathrm{i}}}{\mathrm{n}}=\frac{2675}{33}=81,06 \\
& \text { Percentage of completeness }(p) \text { Pretest }=\frac{8}{33} \times 100 \%=24,24 \% \\
& \text { Percentage of completeness }(p) \text { Posttest }=\frac{28}{33} \times 100 \%=84,85 \%
\end{aligned}
$$

Based on the analysis it was found that the percentage of posttest was greater than the percentage of pretest $(84,85>24,24 \%)$ and was in the Good criteria. So, it can be concluded that

\begin{tabular}{|c|c|c|c|c|c|c|c|c|c|}
\hline & & \multicolumn{5}{|c|}{ Paired Differences } & \multirow{3}{*}{$\mathrm{t}$} & \multirow{3}{*}{ df } & \multirow{3}{*}{$\begin{array}{l}\text { Sig. (2- } \\
\text { tailed) }\end{array}$} \\
\hline & & \multirow[t]{2}{*}{ Mean } & \multirow{2}{*}{$\begin{array}{c}\text { Std. } \\
\text { Deviation }\end{array}$} & \multirow{2}{*}{$\begin{array}{l}\text { Std. Error } \\
\text { Mean }\end{array}$} & \multicolumn{2}{|c|}{$\begin{array}{c}95 \% \text { Confidence Interval } \\
\text { of the Difference }\end{array}$} & & & \\
\hline & & & & & Lower & Upper & & & \\
\hline Pair 1 & $\begin{array}{l}\text { Pretest - } \\
\text { Posttest }\end{array}$ & 27,121 & 8.481 & 1.476 & 24.114 & 30.128 & 18.371 & 32 & .000 \\
\hline
\end{tabular}
teaching material (LKM) based on guided discovery is effective to use, then paired t-test with the help of SPSS 25 software, to find out the significance of an increase in student test results can be seen in table 2 below.

Table 2. Paired Samples Test

Hypothesis

$\mathrm{H}_{0}: \mu_{1}=\mu_{2}$ (There is no difference in student learning achievement before and after using LKM based guided discovery) 
$\mathrm{H}_{\mathrm{a}}: \mu_{1} \neq \mu_{2}$ (There are differences in student learning achievement before and after using LKM based guided discovery)

Significance level $(\alpha)=5 \%=0.05 \mathrm{t}_{\text {table }}=\mathrm{t}_{(0,05 ; 32)}=2,037$

Decision making:

If $t_{\text {count }}(18,3715)>t_{\text {table }}(2,037)$ then $\mathrm{H}_{0}$ is rejected. This means that there are differences in student learning achievement before and after using an LKM

\section{Conclusion}

Based on the results of research and discussion, it can be concluded that, the feasibility of the Student Worksheet (LKM) based on guided discovery and the application of the LKM based on guided discovery in learning, is effective enough to foster understanding of student concepts.

\section{Acknowledgements}

Thanks to the Department of Building Engineering, at the Medan State University for competitiveness research at the faculty level (KDBK) in 2018.

\section{References}

[1] Abdul, M. Perencanaan Pembelajaran, Mengembangkan Standar Kompetensi Guru. Jakarta: PT. Rosda Karya (2008).

[2] Budiningsih, A. Belajar dan Pembelajaran. Jakarta: Rineka Cipta (2005).

[3] Eko, W. P. Evaluasi Program Pembelajaran. Yogyakarta: Pustaka Belajar (2009).

[4] Hendro, D., \& R.E, K. Proyek Pembinaan Tenaga Kependidikan Direktorat Jenderal Pendidikan Tinggi Departemen Pendidikan dan Kebudayaan (1992).

[5] Prastowo, A. Panduan Kreatif Membuat Bahan Ajar Inovati. Yogyakarta: DIVA Press (2011).

[6] Sugiyono. Metode Penelitian Kuantitatif Kualitatif dan R\&D. Bandung: Alfabeta (2012).

[7] Suprihatiningrum, J. Strategi Pembelajaran. Yogyakarta: A-Ruzz Media (2012). 